\title{
ВПЛИВ КЛАТРОХЕЛАТУ ФЕРУМУ(IV) НА ВМІСТ ЦЕРУЛОПЛАЗМІНУ В СИРОВАТЦІ КРОВІ ПОРОСЯТ
}

\author{
Деркач Ірина Михайлівна \\ к.вет.н., доцент \\ Національний університет біоресурсів і природокористування України (м. Київ, Україна) \\ ORCID: 0000-0002-0149-7923 \\ Irina1215@ukr.net \\ Духницький Володимир Богданович \\ д.вет.н., професор \\ Національний університет біоресурсів і природокористування України (м. Київ, Україна) \\ ORCID: 0000-0002-9670-1244 \\ Деркач Сергій Степанович \\ к.вет.н., доцент \\ Національний університет біоресурсів і природокористування України (м. Київ, Україна) \\ ORCID: 0000-0002-6174-1377 \\ Фрицький Олег Ігорович \\ д.хім.н., профессор \\ Київський національний університет імені Тараса Шевченка (м. Київ, Україна) \\ ORCID: 0000-0002-1092-8035 \\ Плутенко Максим Олександрович \\ к.хім.н., науковий співробітник \\ Київський національний університет імені Тараса Шевченка (м. Київ, Україна) \\ ORCID: 0000-0002-9369-0711 \\ Лозовий Віталій Миколайович \\ молодший науковий співробітник \\ Національний університет біоресурсів і природокористування України (м. Київ, Україна)
}

ORCID: 0000-0002-5057-2838

Організм поросят має біологічні особливості, які зумовлюють їх схильність до захворювання на ферумдефріцитну анемію. Це пояснюється тим, що гемоцитопоетичні процеси в їх організмі не забезпечують в достатній мірі продукування еритроцитів та синтез гемоглобіну. Поряд із застосуванням фрерумвмісних препаратів для профрілактики ферумдефріцитного стану зростає ризик активації перекисного окислення ліпідів. Тому за вивчення формако-токсикологічних властивостей нових протианемічних лікарських засобів з діючою речовиною Ферум потребує дослідження прояв їх прооксидантних властивостей в організмі тварини.

Для виконання поставленої мети було сфрормовано 2 групи новонароджених поросят-аналогів у період їх утримання зі свиноматками на підсосі - контрольна та дослідна, по 15 тварин у кожній. Дослід тривав 30 діб. Поросята дослідної групи були відібрані від свиноматок, яким в період вагітності двічі внутрішньом'язово вводили по 10 мл 10 \% розчину клатрохелату Феруму(IV) та розчин ціанокобаламіну. Поросятам контрольної групи згідно традиційної схеми профрілактики фрерумдеффіцитної анемії вводили фрерумдекстрановий препарат (з розрахунку 200 ме Феруму(III) на одне введення).

Результати досліджень засвідчують, що упродовж найбільш критичного для розвитку фрерумдефріцитної анемії періоду, на 9, 12 та 30 доби життя поросят дослідної та контрольної груп, не було виявлено відмінностей у динаміці змін вмісту церулоплазміну у сироватиі крові.

Запропонована схема профілактики фрерумдефіцитної анемії на основі внутрішньом'язового паралельного введення розчинів клатрохелату Феруму (IV) та ціанокобаламіну вагітним свиноматкам за 14 та 7 діб до очікуваного опоросу виявилась ефрективною, причому за відсутності народження мертвих плодів та клінічних ознак анемії.

Ключові слова: анемія, ферум, гексагідразидний клатрохелат, церулоплазмін, поросята, свиноматки.

DOI https://doi.org/10.32845/bsnau.vet.2021.2.4

Вступ. Ферум $є$ одним 3 найбільш важливих мікроелементів для організму тварини, беручи участь у різних життєвонеобхідних біохімічних процесах. Близько $60 \%$ його знаходиться у крові, біля $20 \%$ - у печінці, селезінці, кістковому мозку, решта витрачається на синтез клітинних ензимів. Ферум $є$ необхідною складовою ферумвмісних та ферумзалежних ензимів, що забезпечують функціонування клітин, оптимальний рівень ліпоперекисів, антиоксидантний захист й уцілому фізіологічний статус організму (Bonkovsky\&Herbert, 1991; Karput'\&Nikoladze, 2003; M. G. Ganz, T. 2013).

Майже весь Ферум в організмі тварини знаходиться у формі органічних сполук, які поділяють на дві групи: сполуки, які містять Ферум у складі гему (гемопротеїни) та негемінові сполуки (трансфрерин, фреритин, гемосидерин). Феритин $є$ основним білком, який концентрує і нагромаджує у своєму складі Ферум, проте його концентрація у сироватці крові новонароджених поросят 
низька (лише 0,57 мг/л) (Антоняк, та ін., 2006; Bahramov, et al., 2014). Зі збільшенням вмісту Феруму у клітинах значна його частка відкладається у складі гемосидерину. Найбільша кількість останнього знаходиться у клітинах ретикулоендотеліальної системи (Wilkinson, 2006).

Хоча наслідками надлишку Феруму в організмі тварин і людини є важкі патологічні стани, у тому числі й онкологічного характеру, до питання його дефріциту в усьому світі постійно прикута увага як науковців, так і власників тварин чи тваринницьких господарств.

Особливе значення дефіцит Феруму має для новонароджених поросят. Це пояснюється тим, що за народження із всіх сільськогосподарських тварин поросята $€$ найбільш незрілими. Їх інтенсивний ріст значно випереджає формування органів еритроцитопоезу і досконалість їх функціональної діяльності. Гемоцитопоетичні процеси не забезпечують в достатній мірі продукування еритроцитів та синтез гемоглобіну. У цей період відбувається гальмування еритроцитопоезу у селезінці та печінці, проте активізується процес перебудови еритроцитопоетичної здатності кісткового мозку. Ця біологічна особливість поросят $є$ суттєвим фактором, що зумовлює їх схильність до захворювання на анемію (Karput', \& Nikoladze, 2001; Svoboda\&Drabek, 2005; Sidorkin, et al., 2007; Gasanov, et al., 2020).

Важливу роль в обміні Феруму відіграє купрумумісний білок крові церулоплазмін (або фероксидаза), який за хімічною структурою належить до $\alpha_{2}$-глобулінів. Він бере участь у метаболізмі Феруму та в багатьох окисно-відновних реакціях. Подібність у структурі оксидазного центру церулоплазміну з ктивними центрами інших купрумвмісних оксидаз забезпечує його фероксидазну й антиоксидазну активність (Chen, et al., 2003). Головним джерелом синтезу церулоплазміну в організмі $€$ печінка, а переважна його кількість міститься у плазмі крові й становить 300-580 мг/л. Також він знаходиться у синовіальній рідині та в м'язових тканинах. Рецептори до церулоплазміну виявлені на купферівських клітинах, фрібробластах, астроцитах, еритроцитах, лейкоцитах і моноцитах, мембранах клітин аорти і кардіоміоцитів. У свою чергу, така поширеність рецепторів вказує на важливу роль церулоплазміну в організмі (Vashhenko\&Vashhenko, 2008; Hrytsulia, 2020).

У цьому разі слід зазначити про вагому функцію Купруму в організмі, зокрема його участь разом з Ферумом у процесах кровотворення. Не входячи у склад молекули гемоглобіну, Купрум каталізує включення Феруму у структуру гема і тому є незамінним активатором утворення гемоглобіну (Dorozhkin, 1996).

Церулоплазмін зв'язує майже весь Купрум, який надходить в організм 3 кормом, транспортує його до тканин, де він вивільняється. Без церулоплазміну рівень Купруму в крові знижується, але зростає у сечі та сполучній тканині. За такого стану посилюється всмоктування Купруму у кишечнику, що призводить до його надмірного накопичення і негативного впливу на організм. Також церулоплазмін є білком гострої фрази запалення. Його рівень зростає під впливом стресів, за вагітності, інфекційних й аутоімунних хворобах. Одним з пока- зань до визначення рівня церулоплазміну $є$ i анемія (Michael\&Johnny, 2015).

Застосування у медицині даної сполуки все більше розширюється. Так, включення церулоплазміну як препарату супроводу в комплексну терапію онкологічно хворих зменшує ступінь вираженості проявів синдрому ендогенної інтоксикації та анемії, безпосередньо покращує результати лікування (Lytvynenko, et al., 2005).

Останнім часом вчені застосовують показник рівня церулоплазміну для визначення прооксидантних властивостей досліджуваних речовин. Це пояснюється тим, що церулоплазмін - основний зовнішньоклітинний антиоксидант плазми. Цей білок має високу стабільність до токсичної дії активних метаболітів Оксигену. Таким чином, збільшення активності церулоплазміну у плазмі крові сприяє переходу прооксидної форми Феруму в транспортну у складі трансферину і зменшенню пула низькомолекулярного токсичного Феруму у плазмі (Roxana, et al. 1998). Було встановлено, що антиоксидантний ефект церулоплазміну обумовлений його електрон-акцепторними властивостями (Connor\& Bencovic, 1992).

Токарчуком Т. С. (2018) виявлено, що без застосування препаратів вітаміну E і цитратів Цинку, Феруму та Германію у період відлучення і в перші 7-8 діб після відлучення у тварин підвищується вміст церулоплазміну у сироватці крові, як реакція на стреси і підвищення окисних процесів в організмі поросят. Тенденція зменшення вмісту церулоплазміну у сироватці крові поросят із дослідних груп відносно контролю є підтвердженням ефективної антиоксидантної дії препарату, який містить вітамін Е та комплекс цитратів Цинку, Феруму та Германію (Tokarchuk, 2018).

Ряд вчених доводять, що введення ферумдекстранових препаратів ініціює процеси перекисного окислення ліпідів (ПОЛ). 3 іншого боку, у новонароджених поросят активація ПОЛ за впливу активних метаболітів Оксигену супроводжується розвитком анемічного стану.

У живому організмі антиоксидантна система регулює інтенсивність утворення радикалів та знешкодження продуктів пероксидації. Ї̈̈ основним завданням $€$ підтримання рівноваги між інтенсивністю утворення радикалів та потребами організму у фрізіолого-біохімічних аспектах дії радикалів Оксигену та їх похідних, а саме синтезу біологічно-активних речовин, регуляції проникності мембран. Дана система поділяється на ферментативну (супероксиддисмутаза, каталаза, глутатіонредуктаза, глутатіонтрансфераза, глутатіонпероксидаза) та неферментативну (вітаміни, фрлавоноїди, меланіни, похідні індоламіну, гормони). Дослідження багатьох вчених доводять про активацію перекисного окиснення ліпідів за різних патологій. Інтенсифікація даного процесу спричиняє дезорганізацію структури біологічних мембран, пригнічення активності життєво важливих ензимів, пошкодження ДНК, РНК, хроматину ядра. У свою чергу, гальмування активності ПОЛ може призводити до порушення синтезу деяких біологічно активних речовин та $€$ свідченням зниження фрагоцитозу (Buchko, et al., 1998; Snitynskyi, et al., 1998; Danchuk, 2013). Атипов О. (2013) доводить, що за фрерумдефіцитної анемії у поросят 
зростає генерація активних фрорм Оксигену та інтенсивність вільнорадикального окислення з достовірним зростанням у плазмі крові рівня вторинних продуктів ліпопероксидації за незначного зниження антиокислювальної здатності сироватки крові.

Отже, виснаження ендогенної антиоксидантної системи, активація процесу вільнорадикального окиснення та тканинна гіпоксія спостерігаються за розвитку ферумдефіцитної анемії (Kogan, et al., 1991; Droge, 2001). 3 іншого боку, застосування ін'єкційних ферумдекстранових препаратів поросятам призводить до пригнічення антиоксидантних систем оганізму через надлишкове надходження іонів Феруму (Антоняк, та ін., 2006). Це можна вважати одним з вагомих недоліків сучасних протианемічних лікарських засобів.

Нині з даної фармакологічної групи найбільш поширеними у ветеринарній медицині є комплексні препарати на основі Феруму(III) та декстрану для парентерального введення. Вони також можуть містити вітаміни, а іноді антибіотики та мікроелементи, такі як Кобальт, Купрум, Цинк тощо. Їх ефективність може відрізнятися, оскільки вміст Феруму у даних лікарських засобах коливається у межах від 50 до 200 мг в 1 мл, а також за рахунок особливостей полісахаридних основ можливі різні фізико-хімічні властивості препарату. Зазвичай, це в'язкий темно-коричневого кольору колоїдний розчин, який рекомендують вводити поросятам на 2-4 добу життя однократно (за потреби двократно) внутрішньом'язево. В організмі тварин препарат через лімфатичну систему надходить у кровотік і захоплюється макрофагами, всередині яких відбувається вивільнення Феруму. Близько $30 \%$ введеного розчину затримується у місці введення, причому особливо за утворення інфільтрату. Після вивільнення 3 комплексу невелика кількість Феруму з'єднується з трансферином і швидко надходить у кістковий мозок. Швидкість дисоціації даного комплексу $€$ непостійною, але утилізується весь Ферум. Вважають, що перевагою ферумдекстранових препаратів над солями Феруму у тому, що одна внутрішньом'язева ін'єкція препарату не лише попереджує розвиток анемії, а й створює депо Феруму на довгий період (Gurevichev, et al., 2007), проте лікарські засоби з даної фармакологічної групи мають і ряд недоліків (Delcov\&Gurevichev, 2007; Delcov\&Antipov, 2013; Gasanov, et al., 2020). Розробка нових протианемічних засобів з усуненням побічної негативної дії не втрачає актуальності.

Раніше нами повідомлялося про ряд доклінічних досліджень гострої та хронічної токсичності, кумулятивних властивостей та клінічних досліджень нової унікальної клатрохелатної форми Феруму високій валентності IV (Духницький, та ін., 2018, 2019, 2020, 2021). Було встановлено протианемічну дію даної сполуки за іiї внутрішньом'язевого введення новонародженим поросятам. Встановлено, що клатрохелат Феруму(IV), розчинений у воді для ін'єкцій та реополіглюкіні, мав вищу протианемічну активність порівняно з контролем, про що засвідчила динаміка вірогідних змін кількості еритроцитів, вмісту гемоглобіну та величини гематокриту, вмісту Феруму у сироватці крові та його масової частки у крові, печінці та селезінці поросят. Ефективність дії клатрохелату Феруму(IV) можна пояснити повноцінним забезпеченням організму поросят Ферумом та його вищою біологічною доступністю. Наступним етапом наших досліджень стало вивчення його прооксидантних властивостей.

Зважаючи на те, що останнім часом повідомляється про нові комплексні препарати, у яких Ферум(III) комбінується з ціанокобаламіном чи фолієвою кислотою, нами паралельно 3 ін'єкціями розчину клатрохелату Феруму(IV) застосовувалися ін'єкції розчину ціанокобаламіну як антианемічного вітаміну, необхідного для кровотворення. У формі кобамаміду він сприяє дозріванню еритроцитів, бере участь у синтезі та накопиченні в них сполук, які містять сульфгідрильні групи, що збільшує їх толерантність до гемолізу; має метаболічну функцію та позитивно впливає на функцію печінки та нервової системи.

Мета роботи - вивчити вплив на антиоксидантний статус організму поросят нової схеми профілактики ферумдефіцитної анемії поросят на основі застосування клатрохелату Феруму(IV) поросним свиноматкам.

\section{Матеріал та методи дослідження}

Для виконання поставленої мети було сформовано 2 групи новонароджених поросят-аналогів (гібриди порід ландрас та велика біла) у період їх утримання зі свиноматками на підсосі - контрольна та дослідна, по 15 тварин у кожній.

У дослідну групу були відібрані поросята від 5-ти свиноматок (по 3 від кожної), яким в період вагітності двічі (за 14 та 7 діб до очікуваного опоросу) внутрішньом'язово вводили по 10 мл $10 \%$ розчин клатрохелату Феруму(IV) та розчину ціанокобаламіну (у дозі для свиноматок, рекомендованій офріційними інструкціями, - з розрахунку по 500 мкг діючої речовини на одне введення).

Поросятам контрольної групи за традиційною схемою профрілактики ферумдефіцитної анемії на другу добу життя вводили ферумдекстрановий препарат юніфрерон у дозі 1 мл для тварини (200 мг на одне введення).

Діючою речовиною препарату, що застосовували свиноматкам, $є$ Ферум у рідкісній валентності IV та у формі клатрохелату - це макробіциклічний комплекс, у якому іон металу «упакований» у нанокапсулу, яка перешкоджає взаємодії з переважною більшістю реагентів, зокрема, біолігандами, а також екранує метал від інших факторів навколишнього середовища. Вперше про синтез унікальних клатрохелатних сполук Феруму(IV) було повідомлено Tomyn et al. (2017). Ми провели ряд доклінічних досліджень їх гострої та хронічної токсичності, кумулятивних властивостей та клінічних досліджень (Духницький, та ін., 2018, 2019, 2020, 2021).

Використаний нами розчинник реополіглюкін є плазмозамінним колоїдним розчином декстрану (полімеру глюкози), містить, окрім декстрану, натрію хлорид та воду для ін'єкцій.

Протягом одного місяця за поросятами вели спостереження, для визначення церулоплазміну у сироватці крові поросят відбирали зразки крові на 9, 12 та 30 доби життя. 


\section{Результати досліджень та їх обговорення.}

Як і в попередніх, проведених нами, клінічних дослідженнях клатрохелату Феруму(IV), не відмічалося народження мертвих поросят та не спостерігалося будьяких клінічних ознак анемії, таких як блідості слизових оболонок, скуйовдженості щетини, сухості чи зморщення шкіри поросят, а також прискорення пульсу чи ритму дихання у них, відставання у рості, розладів травлення, малорухливості.

Причому поросята активно ссали свиноматок, природньо займаючи соски з більшим рівнем лактації, що відповідно впливало на підвищення їх продуктивності. Тварини дослідної групи були більш активними, ніж поросята контрольної групи.

Особливу увагу під час проведеного досліду, який тривав 30 діб, було зосереджено на динаміці біохімічних показників сироватки крові поросят дослідної групи порівняно з контролем у ймовірний період прояву ферумдефріцитної анемії.

Як відомо, визначення вмісту церулоплазміну в сироватці крові може слугувати маркером прооксидантної активності досліджуваної сполуки. За вивчення властивостей клатрохелату Феруму(IV) даний показник ми визначали, починаючи з 9 доби життя поросят (табл.).

Таблиця

Уміст церулоплазміну у сироватці крові поросят за впливу різних ферумвмісних препаратів, г/л (M $\pm m, n=15)$

\begin{tabular}{|c|c|c|}
\hline \multirow{2}{*}{$\begin{array}{c}\text { Вок } \\
\text { діб }\end{array}$} & \multicolumn{2}{|c|}{ Група поросят } \\
\cline { 2 - 3 } & І контрольна & І дослідна \\
\hline 9 & $0,6 \pm 0,00$ & $0,6 \pm 0,00$ \\
\hline 12 & $0,7 \pm 0,00$ & $0,7 \pm 0,00$ \\
\hline 30 & $0,7 \pm 0,00$ & $0,7 \pm 0,00$ \\
\hline
\end{tabular}

Примітка: ступінь вірогідності - *** $-p<0,001$; порівняно з показником у поросят контрольної групи

На 9, 12 та 30 доби життя у сироватці крові поросят дослідної групи вміст церулоплазміну не відрізнявся від вмісту церулоплазміну у сироватці крові поросят контрольної групи. Слід зауважити, що динаміку змін умісту церулоплазміну визначали за відсутності у поросят прояву клінічних ознак ферумдесріцитної анемії у період, який вважається критичним для розвитку даної патології.

Вплив препаратів Феруму на процес перекисного окислення даного мікроелемента в організмі тварини, яким вони вводяться, донині залишається дискусійним питанням та потребує більш глибокого вивчення. Результати досліджень деяких вчених вказують, що у процесі біотрансформації лікарські засоби з діючою речовиною Ферумом не потребують окиснення та, відповідно, не володіючи прооксидантними властивостями, не викликають утворення вільних радикалів (Latour, et al., 1992). Проте $є$ твердження, що виділення іонів Феруму з таких сполук можливе (Belousova, et al., 2009).

Відомо також, що за гіпоксії наслідком процесу відновлення іонів Феруму(III) до Феруму(II) $є$ перенесення електронів від іонів Феруму(II) до пероксиду Гідроводню (Ganz, 2013). Вважається, що навіть незначне підви- щення концентрації в організмі вільних іонів металів, яким властиві перехідні валентності, спричиняє небажані реакції, пов'язані з молекулярним Оксигеном. У свою чергу, це засвідчує наявність патогенетичного фактора за хвороб, пов'язаних з так званим «окисним стресом». До того ж Ферум як один з найбільш поширених в організмі мікроелемент має найбільший вплив на інтенсивність перебігу реакцій вільно радикального окиснення, беручи участь у реакціях, відомих як реакції Фентона, Хабера-Вайса та Осипова (Антипов, 2011; Danchuk, 2013). Активація змін, пов'язаних з надлишком Феруму, має токсичний вплив на функцію печінки, серцево-судинної системи, гормональний статус, викликає дисфункцію імунної системи (Kang, 2001; Антипов, 2013). Отже, за вивчення фармако-токсикологічних властивостей нових ферумвмісних препаратів дослідження його прооксидантних властивостей є досить актуальним.

Нами вперше досліджувався вплив на перекисне окиснення ліпідів Феруму у формі клатрохелату та в рідкісній валентності - IV. Результати проведених раніше доклінічніх досліджень клатрохелату Феруму(IV) дали підстави провести його клінічні дослідження на продуктивних тваринах як протианемічного лікарського засобу. Такі попередні досліди, проведені на поросятах-сисунах, показали високу протианемічну активність порівняно 3 контролем, де діючою речовиною був Ферум(III). Це можна пояснити повноцінним забезпеченням Ферумом організму поросят-сисунів та його вищою біологічною доступністю.

Особливістю наступних досліджень було те, що препарат на основі клатрохелату Феруму вводився не новонародженим поросятам згідно традиційних інструкцій до ферумдекстранових препаратів, а свиноматкам у період вагітності двічі (за 14 та 7 діб до очікуваного опоросу) внутрішньом'язово по 10 мл $10 \%$ розчин клатрохелату Феруму(IV) та розчину ціанокобаламіну (у дозі для свиноматок, рекомендованій офріційними інструкціями, - з розрахунку по 500 мкг діючої речовини на одне введення). Отримані нами результати вмісту церулоплазміну у сироватці крові поросят, народжених від таких свиноматок, засвідчили про високий антиоксидантний статус організму поросят та відсутність негативного впливу на організм поросят-сисунів нової схеми профрілактики ферумдефіцитної анемії поросят на основі застосування клатрохелату Феруму(IV) поросним свиноматкам.

Висновки. Поряд з іншими показниками, які характеризують інтенсивність вільнорадикального окиснення, такими як уміст дієнових кон'югантів, малонового діальдегіду, індексу утворення шиффових основ тощо, оцінку системи антиоксидантного захисту проводять і за величиною церулоплазміну у сироватці крові.

Згідно результатів проведених нами досліджень, упродовж найбільш критичного для розвитку ферумдефіцитної анемії періоду, на 9, 12 та 30 доби життя поросят дослідної та контрольної груп, не було виялено відмінностей у динаміці змін вмісту церулоплазміну у сироватці крові. Це можна пояснити тим, що виснаження ендогенної антиоксидантної системи, активації процесу вільнорадикального окиснення, що спостерігається 
за розвитку ферумдефіцитної анемії та ін'єкціях фрерумдекстрановими препаратами, нами не відмічено.

Запропонована схема профілактики фрерумдесріцитної анемії на основі внутрішньом'язового паралельного вве- дення розчинів клатрохелату Феруму(IV) та ціанокобаламіну вагітним свиноматкам за 14 та 7 діб до очікуваного опоросу виявилась ефрективною, причому за відсутності народження мертвих плодів та клінічних ознак анемії у поросят.

\section{References}

1. Antipov, A. A. (2013). Patogeneticheskie mekhanizmy razvitiya, diagnostika i profilaktika alimentarnoj zhelezodeficitnoj anemii porosyat (Doctoral dissertation). Retrieved from Disser Cat - elektronnaya biblioteka dissertacij. https://www.dissercat. com/content / patogeneticheskie-mekhanizmy - razvitiya - diagnostika - i - profilaktika - alimentarnoi - zhelezodefits [in Russian].

2. Antipov, A. A., Del'cov, A. A., Sodboev, C. C., \& ZHarov A. V. (2011). Rol'svobodnoradikal'nogo okisleniya v patogeneze zhelezodificitnoj anemii i ee farmakokorrekcii [The role of free radical oxidation in the pathogenesis of iron deficiency anemia and its pharmacological correction]. MGAVMiB - MVA imeni K. I. Skryabina. Moskva,15-19 [in Russian].

3. Antipov, A. A, \& Zharov A. V. (2013). Histological and morphometric changes in the liver, kidneys, spleen and lymph nodes of piglets with alimentary iron deficiency anemia [Gistologicheskie i morfometricheskie izmeneniya pecheni, pochek, selezenki i limfaticheskih uzlov porosyat pri alimentarnoj zhelezodeficitnoj anemii]. Rossijskij veterinarnyj zhurnal. Sel'skohozyajstvennye zhivotnye [Russian veterinary journal. Farm animals], 1, 19-21 [in Russian].

4. Antonyak, G. L., Solohub, L. I., Snitynskyi, V. V., \& Babych, N. O. (2006). Zalizo v orhanizmi lyudyny I tvaryn (biohimichni, imunolohichni ta ekolohichni aspekty) [Iron in humans and animals (biochemical, immunological and environmental aspects)]. Lviv [in Ukrainian].

5. Bahramov, S. M., Kazakbaev, H. M., \& Buglanov, A. A. (2014). Transferrin: rol' v obmene zheleza i nekotorye aspekty [Transferrin: role in iron metabolism and some aspects]. Gematologija i transfuziologija [Hematology and transfusiology], 2, 39-42 [in Russian].

6. Belousova Y. B., Kukesa V. G., Lepahina V. K., \& Petrova V. I. (Eds.) (2014). Clinical pharmacology: a national guide [Klinicheskaya farmakologiya: nacional'noe rukovodstvo]. Moskwa, Geotar-Media [in Russian].

7. Bonkovsky, S., \& Herbert, L. (1991). Iron and the liver. The American journal of the medical sciences, 301(1), 32-43. doi.org/10.1097/00000441-199101000-00006

8. Buchko, O. M., Snitynskyi, V. V., Danchuk, V. V., \& Antoniak H. L. (1998). Zastosuvanna spoluk selenu dlia profilaktyky oksydatsiinoho stresu u porosiat rannoho viku [The use of selenium compounds for the prevention of oxidative stress in early piglets of his age]. Haukovyi visnyk Hatsionalnoho Ahrarnoho universytetu [Scientific Bulletin of the National Agrarian University], 10, 156-163 [in Ukrainian].

9. Chen, J., Anderson., J., DeWeese-Scott, C., Fedorova, N., Geer, L., He, S., Hurwitz, D., Jackson, J., Jacobs, A., Lanczycki, Ch., Liebert, C., Liu, Ch., Madej, T., Marchler-Bauer, A., Marchler, G., Mazumder, R., Nikolskaya, A., Rao, B., Panchenko, A., Shoemaker, A., Simonyan, V., Song, J., Thiessen, P., Vasudevan, S., Wang, Y., Yamashita, R., Yin, J., Bryant, S. (2003). MMDB: Entrez's 3D-structure database, NucleicAcids Research, 31, 1, 474-477, https://doi.org/10.1093/nar/gkg086

10. Danchuk, O. V. (2013). Peroksydne okysnennia lipidiv ta aktyvnist systemy antyoksydantnoho zakhystu u porosiatsysuniv pid vplyvom preparativ zaliza [Peroxidation of lipids and the activity of the antioxidant defense system in suckling piglets under the influence of iron preparations]. Svynarstvo [Swine breeding], 62, 89-93 [in Ukrainian].

11. Del'cov, A. A. Antipov, A.A. (2013). Morphological changes in the liver and kidneys of piglets with iron deficiency anemia [Morfologicheskie izmeneniya pecheni i pochek porosyat pri zhelezodeficitnoj anemii]. Veterinary [Veterinariya], 4, 46-49

12. Del'cov, A. A., Gurevichev, P.A. (2007). Study of toxicity parameters of new iron-dextran preparations [lzuchenie parametrov toksichnosti novyh zhelezodekstranovyh preparatov]. Materials of the II All-Russian Scientific and Practical Conference of Young Scientists "Youth and Science of the XXI Century" [Materialy II Otkrytoj Vserossijskoj nauchnoprakticheskoj konferencii molodyh uchenyh «Molodezh' i nauka XXI veka»]. Ul'yanovsk, 57-61.

13. Dorozhkin, V. I. (1996). Rezul'taty issledovanij biologicheskoj aktivnosti metionata medi [The results of research on the biological activity of media methonates]. Materialy nauchnoj konferencii, posvjashhennye 50-letiju Krasnodarskoj AIVS «Sostojanie i perspektivy razvitija nauchnyh issledovanij po profilaktike i lecheniju sel'skohozjajstvennyh zhivotnyh i ptic». Krasnodar, 91-92 [in Russian].

14. Droge, W., (2001). Free radicals in the physiological control of cell ruction. Physiological reviews, 82. 47-95.

15. Dukhnitsky, V. B., Derkach, I. M., Plutenko, M. O., Fritsky, I. O., \& Derkach, S. S. (2018). Vyznachennja parametriv gostroi toksychnosti ferumu (IV) na bilyh myshah [Determination of the accumulative toxicity parameters of iron (IV) on white mice]. Ukrainian Journal of Ecology, 8 (2), 308-312. doi.org/10.15421/2018 343 [in Ukrainian].

16. Dukhnitsky, V. B., Derkach, I. M., Derkach, S. S., Fritsky, I.O., \& Plutenko, M. O. (2019). Khronichna toksychnist klatrokhelatu Ferumu (IV) dlia bilykh shchuriv [Chronic toxicity of the Iron (IV) clathrochelate complexes for white rats]. Naukovyj visnyk Lvivskogo nacionalnogo universytetu veterynarnoi medycyny ta biotehnologij imeni S. Z. Gzhyckogo [Scientific Messenger of LNU of Veterinary Medicine and Biotechnologies. Series: Veterinary Sciences], 21(95), 15-21. https://doi.org/10.32718/nvlvet9503 [in Ukrainian].

17. Dukhnitsky, V. B., Derkach, I. M., Plutenko, M. O., Fritsky, I. O., \& Derkach, S. S. (2019). Cumulative properties of Iron(IV) clathrochelate in rats [Kumuliatyvni vlastvosti klatrokhelatu Ferumu (IV) dlia bilykh shchuriv]. Visnyk PDAA [Messenger PDAA], 2, 238-246. doi: 10.31210/visnyk2019.02.32 [in Ukrainian].

18. Dukhnitsky, V. B., Derkach, I. M., Plutenko, M. O., Fritsky, I. O., \& Derkach, S. S. (2019). Acute toxicity of the iron clathrochelate complexes. Regulatory Mechanisms in Biosystems, 10(3), 276-279. https://doi.org/10.15421/021942

19. Dukhnitsky, V. B., Derkach, I. M., Derkach, S. S., Plutenko, M. O. \& Fritsky, I. O. (2019). Influence of iron (IV) clathrochelate complex on quail blood parameters and weight characteristics. Ukrainian Journal of Ecology, 9 (3), $126-131$. DOI: $10.15421 / 2019 \_719$ 
20. Dukhnitsky, V. B., Derkach, I. M., Derkach, S. S., Fritsky, I. O., \& Plutenko, M. O. (2020). Doslidzhennia podrazniuvalnoi dii ta alerhennykh vlastyvostei klatrokhelatu Ferumu(IV) [Investigations of the irritant effect and allergenic properties of Fermat's clatrochelate (IV)]. Naukovyj visnyk Lvivskogo nacionalnogo universytetu veterynarnoi medycyny ta biotehnologij imeni S. Z. Gzhyckogo [Scientific Messenger of LNU of Veterinary Medicine and Biotechnologies. Series: Veterinary Sciences], 22(97), 130-135. doi: 10.32718/nvlvet9721 [in Ukrainian].

21. Dukhnitsky, V. B., Derkach, I. M., Derkach, S. S., Fritsky, I. O., \& Plutenko, M. O. (2020). Doslidzhennia protyanemichnoi dii klatrokhelatu Ferumu(IV) na porosiatakh [Study of the antianemic effect of iron (IV) clatrochelate on piglets]. Naukovyj visnyk Lvivskogo nacionalnogo universytetu veterynarnoi medycyny ta biotehnologij imeni S. Z. Gzhyckogo [Scientific Messenger of LNU of Veterinary Medicine and Biotechnologies. Series: Veterinary Sciences], 22(99), 107-115. doi: 10.32718/nvlvet9917 [in Ukrainian].

22. Dukhnitsky, V. B., Kalachniuk L. H., Derkach, I. M., Derkach, S. S., Plutenko, M. O. \& Fritsky, I. O. (2020). Iron(IV) hexahydrazide clathrochelate complexes: the chronic toxicity study. Ukrainian Journal of Ecology, 9 (3), 18-23. DOl: 10.15421/2020_3

23. Ganz, T. (2013). Systemic iron homeostasis. Physiological Reviews, 93 (4), 1721-1741. doi: 10.1152/physrev.00008

24. Gasanov, A. S., Amiov, D. R., Muhutdinova, D. M., Ovsjannikov, A. P., Churna, Z. G., \& Shamsutdinova, N. V. (2020). Anemija i preparaty, primenjaemye pri ee lechenii i profilaktike [Anemia and drugs used in its treatment and prevention]. Kazan' [in Russian].

25. Gurevichev P. A., Del'cov A. A., \& Urazaev D. N. (2007). Iron dextran preparations in veterinary medicine [Zhelezodekstranovye preparaty v veterinarii]. Materialy pervogo s"ezda veterinarnyh farmakologov Rossii [Proceedings of the first congress of veterinary pharmacologists of Russia]. Materialy s"ezda. Voronezh, 699 [in Russian].

26. Kang, J. O. (2001). Chronic iron overload and toxicity: clinical chemistry perspective. Clinical Laboratory Science Journal, 14 (3), 209-219.

27. Hrytsulia, M. (2020). Tseruloplazmin: praktychni aspekty zastosuvannia dlia pryskorenoho vidnovlennia patsiientiv khirurhichnoho profiliu [Ceruloplasmin: practical aspects of application for accelerated recovery of patients with a surgical profile]. Khirurhiia, Ortopediia, Travmatolohiia, Intensyvna terapiia [Surgery, Orthopedics, Traumatology, Intensive Care], 1, 39 [in Ukrainian].

28. Karput', I. M., \& Nikoladze, M. G. (2001). Diagnostika i profilaktika alimentarnoj anemii porosjat [Diagnosis and prevention of alimentary anemia of piglets]. Veterinarija [Veterinary medicine], 4, 34-37 [in Russian].

29. Karput' I. M., \& Nikoladze M. G. (2003). Obmen zheleza u zdorovyh i bol'nyh alimentarnoj anemiej porosjat [Iron metabolism in healthy and sick piglets with alimentary anemia]. Bulletin of the Academy of Agrarian Sciences of the Republic of Belarus [lzvestiya Akademii Agrarian Sciences of the Republic of Belarus], 4, 34-37 [in Russian].

30. Kogan, A. H., Ershov, V. I., \& Alekperova, G. R. (1991). Costojanie svobodnoradikal'nyh processov pri zhelezodeficitnyh anemijah [The state of free radical processes in iron deficiency anemia]. Terapevticheskij arhiv [Therapeutic archive], 63, 7, 85-88.

31. Latour, I., Pregaldien, P., \& Buc-Calderon (1992). Cell death and Lipid peroxidation in isolated hepatocytes incubated in the presence of hydrogen peroxide and iron salts. Archives of Toxicology, 66, 743-749.

32. Lytvynenko, O., Kaban, O., Hunina, L., Sorokin, B., Yehorov, I., Zhukov, Yu., Leshchuk, L., \& Lytvynenko O. (2005). Zastosuvannia tseruloplazminu dlia profilaktyky uskladnen kompleksnoho likuvannia khvorykh onkolohichnoho profiliu [The use of ceruloplasmin for the prevention of complications of complex treatment of cancer patients]. Ukrainskyi khimioterapevtychnyi zhurnal [Ukrainian Chemotherapeutic Journal], 1-2, 69-72 [in Ukrainian].

33. Michael, A., \& Johnny, L. (2015). Ceruloplasmin and Hypoferremia: Studies in Burn and Non-Burn Trauma Patients. Antioxidants 4, 153-169; doi:10.3390/antiox4010153.

34. Roxana, L., Dino S., Mircea, A., Catherine, V., Florence, D., François, B., Véronique M., Réginald, N., \& Luc, R. (1998). Direct evidence of caeruloplasmin antioxidant properties. Molecular and Cellular Biochemistry, 189, 127-135. https://doi.org/10.1023/A:1006945713860

35. Sidorkin, V., Gavrish, V., Egunova, A., \& Ubiraev, V. (2007). Bolezni svinej. [Diseases of swine]. Akvarium - print, Moskwa [in Russian].

36. Snitynskyi, V. V., Danchuk, V. V., \& Buchko, O. M. (1998). Aktyvnist antyoksydantnykh fermentiv ta in-tensyvnist protsesiv vilnoradykalnoho okyslennia u tkanynakh svynei u period postnatalnoi adaptatsii [Activity of anti-oxidant enzymes and intensity of free-radical processes oxidation in pig tissues during post-natal adaptation]. Ukrainskyi biokhimichnyi zhurnal [Ukrainian Biochemical Journal], 70, 105-110 [in Ukrainian].

37. Svoboda, M., \& Drabek, J. (2005). Iron deficiency in suckling piglets: etiology, clinical aspects and diagnosis. Folia Veterinaria:;49:104-111.

38. Tokarchuk, T. S. (2018). Pokaznyky antyoksydantnoho statusu v syrovattsi krovi porosiat za vykorystannia vitaminu $\mathrm{E}$ i tsytrativ $\mathrm{Zn}, \mathrm{Fe}$ ta Ge [Indicators of antioxidant status in the serum of piglets using vitamin $\mathrm{E}$ and citrates $\mathrm{Zn}$, Fe and Ge]. Tekhnolohiia vyrobnytstva i pererobky produktsii tvarynnytstva [Technology of production and processing of livestock products], 1, 7-83 [in Ukrainian].

39. Tomyn, S., Shylin, S. I., Bykov, D., Ksenofontov, V., Gumienna-Kontecka, E., Bon, V. \& Fritsky, I.O. (2017) Indefinitely stable iron (IV) cage complexes formed in water by air oxidation. Nature Communications, 8, 1-8.

40. Vashhenko, V. I., \& Vashhenko, T. N. (2008). Biologija i farmakologija ceruloplazmina: ot jeksperimenta do lekarstvennoj terapii [Biology and pharmacology of ceruloplasmin: from experiment to drug therapy]. Obzory po klinicheskoj farmakologii i lekarstvennoj terapii. Voenno-medicinskaja akademija im. S.M. Kirova, S. Peterburg, T. 6 [in Russian].

41. Wilkinson, J., Di X., Schönig, K., Buss, J., Kock, N., Cline, M., Saunders, T., Bujard, H., Torti, S., \& Torti, F. (2006). Tissue-specific expression of ferritin $\mathrm{H}$ regulates cellular iron homoeostasis in vivo. Biochemical Journal. 395(3), 501-507. doi: https://doi.org/10.1042/BJ20060063 
Iryna Derkach, National University of Life and Environmental Sciences of Ukraine

Volodymyr Dukhnitskyi, National University of Life and Environmental Sciences of Ukraine

Sergii Derkach, National University of Life and Environmental Sciences of Ukraine

Igor Fritsky, Taras Shevchenko National University of Kyiv

Maksym Plutenko, Taras Shevchenko National University of Kyiv

V. M. Lozovyi, National University of Life and Environmental Sciences of Ukraine

Effect of iron(iv) clatrochelate on ceruloplasmin content in blood serum of piglets

The body of piglets has biological features that determine their susceptibility to iron deficiency anemia. This is due to the fact that hemocytopoietic processes in their body do not provide sufficient production of erythrocytes and hemoglobin synthesis. Along with the use of iron-containing drugs for the prevention of iron deficiency, the risk of activation of lipid peroxidation increases.

To achieve this goal, 2 groups of newborn piglets-analogues were formed during their retention with suckling sows control and experimental, 15 animals in each. The experiment lasted 30 days. The piglets in the experimental group were selected from sows given $10 \mathrm{ml}$ of $10 \%$ iron (IV) clatrochelate solution and cyanocobalamin solution twice intramuscularly during pregnancy. The piglets of the control group according to the traditional scheme of prevention of iron deficiency anemia on the second day of life were administered iron dextran drug (at the rate of $200 \mathrm{mg}$ of iron (III) per injection).

The results show that during the most critical period for the development of iron deficiency anemia, on the 9,12 and 30 days of life of piglets in the experimental and control groups the differences in the dynamics of changes in the content of ceruloplasmin in the serum were not detected.

The proposed scheme for the prevention of iron deficiency anemia based on intramuscular parallel administration of solutions of iron(IV) clatrochelate and cyanocobalamin to pregnant sows on the 14 and 7 days before the expected farrowing was effective, and in the absence of stillbirths and the clinical signs of anemia.

Key words: anemia, iron, hexahydrazide clatrochelate, ceruloplasmin, piglets, sows. 